\title{
A peptide release system using a photo-cleavable linker in a cell array format for cell-toxicity analysis
}

\author{
Takashi Kakiyama ${ }^{1,5}$, Kenji Usui ${ }^{1,2,3,5}$, Kin-ya Tomizaki ${ }^{4}$, Masayasu Mie ${ }^{2}$, Eiry Kobatake ${ }^{2}$ \\ and Hisakazu Mihara ${ }^{1}$
}

We constructed a novel peptide-array format system for cellular toxicity analysis. In this system, a peptide was immobilized on a conventional 96-well plate bottom via a photo-cleavable linker. Once UV light irradiated the desired wells, the peptide was released from the bottom. As a result, the cytotoxic behavior of the peptide could be monitored. Immobilization and lightirradiation conditions were optimized. The immobilized peptide showed no cytotoxicity; therefore, the cells could be cultured on the peptide-immobilizing plate from the beginning of the experiment. Cell-toxicity assays with this system for three cell types were performed. All cell types showed $\sim 25 \%$ lowering of viability with the photo-released 5 -(and-6)carboxytetramethylrhodamine (TMR)-GKLAKLAKKLAKLAKKLAKLAKGC (TMR-KLA-C) peptide compared with the non-coated plate. This relative toxicity nearly corresponded to that of $\sim 10 \mu \mathrm{M}$ TMR-KLA-C in solution, and we found that the released peptide concentration per well was $\sim 10 \mu \mathrm{m}$ at $60 \mathrm{~min}$ irradiation. Throughout this study, we successfully immobilized peptides via the photo-cleavable linker, released them by UV irradiation spatiotemporally and conducted the cell-toxicity assay. This study implies that the peptide photo-releasing array system will allow the realization of high-throughput cell arrays for cellomics analyses and cell-based phenotypic drug screenings.

Polymer Journal (2013) 45, 535-539; doi:10.1038/pj.2013.20; published online 27 February 2013

Keywords: cell microarray; cytotoxicity; peptide microarray; photo-cleavage linker

\section{INTRODUCTION}

After the elucidation of genome sequences in various organisms, significant advances in 'omics' studies have opened up cellomics research based on cell-based phenotypic assays ${ }^{1}$ for studying vital cellular phenomena., ${ }^{2,3}$ To analyze the phenotypic consequences of mammalian cells with chemical stimulants including drugs, systematic cell-based assays in a high-throughput screening format are increasingly indispensable. Cell microarrays provide an attractive solution, as they offer more than a simple miniaturization and mechanization of conventional equipment. From this point of view, we have constructed peptide microarrays composed of various secondary structures, ${ }^{4-9}$ and have initially applied the designed peptide arrays to protein-analysis systems. ${ }^{10-14}$ We then began to explore the designed peptide arrays for use in cell microarrays. In our cell array technique, the obtained cellular response patterns upon stimulation with library peptides were regarded as 'cell fingerprints', which revealed how peptide properties affect a particular cell type. ${ }^{15}$ In addition, by applying statistical analyses, such as hierarchical clustering analysis, to cell fingerprints, high-confidence correlations between cell types and biological functions were elucidated based primarily upon peptide charge and hydrophobicity data.

As is done for the development of protein microarray technology, ${ }^{6}$ we are currently focusing on development of a more practical array format ${ }^{16-19}$ and on achievement of a more detailed detection and analysis method for use in cellular research. Consequently, in this study we attempted to construct a peptide photo-release system for cytotoxicity analysis (Figure 1a). Initially, a peptide is immobilized on a commercially available plastic culture plate bottom via a photo-cleavable linker. For the toxicity assay, UV light irradiation on the desired wells in a 96-well plate releases the peptide from the plate bottom. After the irradiation and release of the peptide, the cytotoxic behavior of the peptide can be monitored.

\footnotetext{
${ }^{1}$ Department of Bioengineering, Graduate School of Bioscience and Biotechnology, Tokyo Institute of Technology, Yokohama, Japan; ${ }^{2}$ Department of Biological Information, Graduate School of Bioscience and Biotechnology, Tokyo Institute of Technology, Yokohama, Japan; ${ }^{3}$ FIRST (Faculty of Frontiers of Innovative Research in Science and Technology) and FIBER (Frontier Institute for Biomolecular Engineering Research), Konan University, Kobe, Japan and ${ }^{4}$ Innovative Materials and Processing Research Center and Department of Materials Chemistry, Ryukoku University, Otsu, Japan

${ }^{5}$ These authors contributed equally to this work.

Correspondence: Dr K Usui, FIRST (Faculty of Frontiers of Innovative Research in Science and Technology) and FIBER (Frontier Institute for Biomolecular Engineering Research), Konan University, 7-1-20 Minatojima-minamimachi, Chuo-ku, Kobe 650 0047, Japan.

E-mail: kusui@center.konan-u.ac.jp

or Professor H Mihara, Department of Bioengineering, Graduate School of Bioscience and Biotechnology, Tokyo Institute of Technology, Nagatsuta-cho 4259 B40, Midori-ku, Yokohama 2268501 , Japan.

E-mail: hmihara@bio.titech.ac.jp

Received 30 September 2012; revised 18 December 2012; accepted 20 December 2012; published online 27 February 2013
} 
a

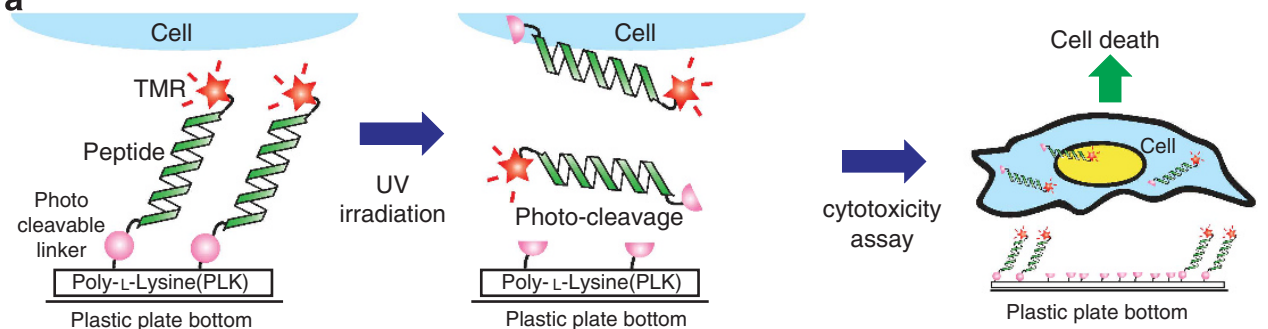

b

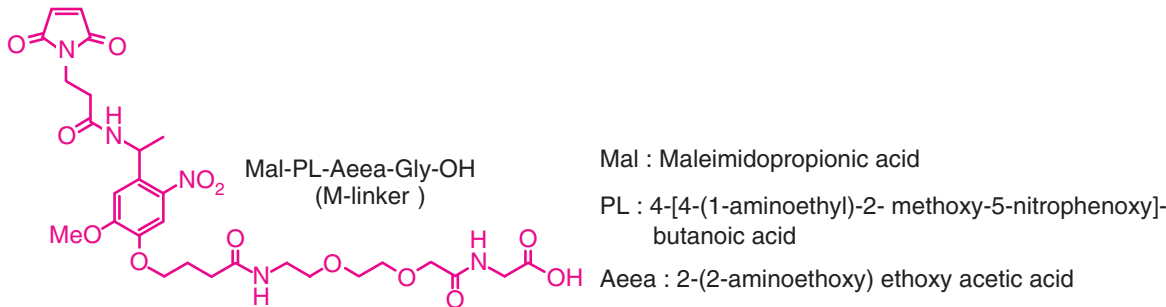

C TMR-KLA-C peptide

TMR-GKLAKLAKKLAKLAKKLAKLAKGC-NH2

TMR : 5-(6)-carboxytetramethylrhodamine

Figure 1 (a) Scheme of the peptide photo-release array system for the cytotoxicity assay. (b) Structure of the photo-cleavable linker (M-linker). (c) Sequence of the TMR-GKLAKLAKKLAKLAKKLAKLAKGC (TMR-KLA-C) peptide.

We have chosen the [4-(1-aminoethyl)-2-methoxy-5-nitrophenoxy]butanoic acid derivative $e^{20-23}$ as a photo-cleavage linker (Figure 1b). This photo linker can be cleaved by irradiation of $365 \mathrm{~nm}$ UV light, which has been proven to be harmless to cells. ${ }^{24,25}$ This system has some advantages as follows: (1) the peptide release can be timecontrolled because light can be irradiated at any time; (2) the peptide release can be site-controlled because light can be irradiated at any position within the micrometer range, offering a single-cell assay; and (3) light irradiation is a relatively easier and cheaper method than other methods, including use of a chemolabile linker. ${ }^{26}$

Here we describe the construction of a novel cell array format using the peptide photo-release system. Initially, we optimized the peptideimmobilization methods and conditions, such as poly-L-lysine molecular weights (m.w.) for coating the bottom of wells, the immobilization time and the UV irradiation time for the release. Next, the cellular viability assay was conducted, revealing the peptide cytotoxicity. This study implies that the peptide photo-releasing array system will allow realization of high-throughput cell or single-cell arrays not only for cytotoxicity analyses but also for other cell-phenotypic analyses and screenings.

\section{EXPERIMENTAL PROCEDURE}

\section{General remarks}

All chemicals and solvents were of reagent or high-performance liquid chromatography grade and were used without further purification. Highperformance liquid chromatography was performed on the Hitachi L7000 (Hitachi High-Technologies, Tokyo, Japan) or the Shimadzu LC2010C systems (Shimadzu, Kyoto, Japan), using a Wakosil 5C18 or a YMC-Pack ODS-A $(4.6 \times 150 \mathrm{~mm}$; YMC, Kyoto, Japan) for analysis, and a YMC ODS A323 $(10 \times 250 \mathrm{~mm})$ for preparative purification, with a linear gradient of acetonitrile/ $0.1 \%$ trifluoroacetic acid at a flow rate of $1 \mathrm{ml} \mathrm{min}^{-1}$ for analyses and $3 \mathrm{mlmin}-1$ for preparative separation, respectively. Matrix-assisted laser desorption-ionization time-of-flight mass spectrometry was measured on a Shimadzu KOMPACT MALDI III, with 3,5-dimethoxy-4-hydroxycinnamic acid as a matrix. Amino acid analysis was carried out using a Wakopak WS-
PTC column $(4 \times 200 \mathrm{~mm}$; Wako Pure Chemical Industries, Osaka, Japan $)$ after hydrolysis in $6 \mathrm{M} \mathrm{HCl}$ at $110^{\circ} \mathrm{C}$ for $24 \mathrm{~h}$ in a sealed tube, followed by phenyl isothiocyanate labeling.

\section{Synthesis of TMR-KLA-C peptide}

The 5-(and-6)-carboxytetramethylrhodamine (TMR)-GKLAKLAKKLAKLA KKLAKLAKGC (TMR-KLA-C) peptide (Figure 1c) was synthesized on NovaSyn TGR resin (Merck Japan, Tokyo, Japan) by manual synthesis with Fmoc chemistry. ${ }^{27}$ Side-chain protections were as follows: $t$-butyloxycarbonyl for Lys and trityl for Cys. Initially, the Fmoc-peptide sequence was synthesized with Fmoc-AA-OH (3 eq.) by the HBTU [2-(1H-benzotriazole-1-yl)-1,1,3,3tetramethyluronium hexafluorophosphate]-HOBt (1-hydroxy benzotriazole monohydrate) method. After the assembly of peptide sequences, the TMR moiety was introduced using TMR (2 eq.) with HBTU (2 eq.), HOBt (2 eq.) and diisopropylethylamine (4 eq.) for $60 \mathrm{~min}$. The peptide with a fluorescent probe was cleaved from the resin, and side-chain protections were removed with trifluoroacetic acid/ $\mathrm{H}_{2} \mathrm{O} /$ triisopropylsilane $(95 / 2.5 / 2.5, \mathrm{vol} / \mathrm{vol})$ at room temperature for $1 \mathrm{~h}$. The peptide was precipitated by the addition of diethylether and collected by centrifugation. The peptide was purified by reverse-phase high-performance liquid chromatography, and was characterized by matrix-assisted laser desorption-ionization time-of-flight mass spectrometry and amino acid analysis. The lyophilized peptide was dissolved every time before use. To estimate the concentration of the solution, the TMR absorbance of a diluted solution of peptides was measured in $20 \mathrm{~mm}$ Tris- $\mathrm{HCl}$ containing $6 \mathrm{~m}$ guanidine hydrochloride ( $\mathrm{pH} 7.0$ ).

\section{Synthesis of photo-cleavable linker (M-linker)peptide}

A photo-cleavable (M-linker) peptide (Figure 1b) was synthesized on 2chlorotrityl chloride resin (Merck) by manual synthesis with Fmoc chemistry. ${ }^{27}$ Initially, Fmoc-Gly-OH (0.5 eq.) was coupled to the resin with diisopropylethylamine (2.5 eq.) in dried dichloromethane (DCM)/N,Ndimethylformamide (DMF; 5/4, vol/vol) using a round-bottom flask equipped with calcium chloride for $60 \mathrm{~min}$. After the reaction, unreacted moieties on the resins were capped by methanol ( $\sim 5 \%$ of the reaction volume) for $15 \mathrm{~min}$. Next, the resins were transferred to a peptide synthesis tube and washed with DCM, methanol and DCM/DMF (1/1, vol/vol). 
The Fmoc group was removed by $20 \%$ piperidine in DCM/DMF $(1 / 1, \mathrm{vol} / \mathrm{vol})$ for $15 \mathrm{~min}$. After removal of Fmoc, the resins were washed with DCM/DMF (1/1, vol/vol) and diethylether. Fmoc-2-(2-aminoethoxy) ethoxy acetic acid, Fmoc-4-[4-(1-aminoethyl)-2-methoxy-5-nitrophenoxy]butanoic acid and maleinimidopropionic acid were coupled by the HBTUHOBt method as previously described. The peptide was cleaved from the resin with acetic acid/trifluoroethanol/dichloromethane $(1 / 1 / 8, \mathrm{vol} / \mathrm{vol})$ at room temperature for $2 \mathrm{~h}$. After removal of the resins, the addition of hexane to the peptide solution and evaporation of the solvent were repeated three to five times. MilliQ reverse osmosis-purified water (Merck) was then added to the evaporated sample, and the peptide solution was lyophilized.

\section{Immobilization of the peptides}

The M-linker $\mathrm{C}$ terminus was activated using $\mathrm{N}$-hydroxysuccinimide (10 eq.) and 1-ethyl-3-(3-dimethylaminopropyl)carbodiimide (10 eq.) in $100 \mu \mathrm{l} \mathrm{DMF}$ (2h). Next, $5 \mu \mathrm{l}$ of the activated M-linker solution and $10 \mu \mathrm{l}$ of poly-L-lysine hydrobromide (PLK, m.w. $=15-30,75-150$ and $150-300 \mathrm{kDa}$ ) in a HEPES buffer (50 mM 2-[4-(2-hydroxyethyl)-1-piperazinyl]ethanesulfonic acid (HEPES), $250 \mathrm{~mm} \mathrm{NaCl}, \mathrm{pH}$ 7) were added to a mixed solution of $95 \mu \mathrm{l}$ of DMF and $90 \mu \mathrm{l}$ of the HEPES buffer, and the solution was incubated for 30 min. The TMR-KLA-C peptide in the HEPES buffer was then added to the reaction buffer, and the reaction solution was incubated for $30 \mathrm{~min}$ to obtain a peptide-M-linker-PLK conjugate (final molar ratio of the reactive species: $\mathrm{NH}_{2}$ of PLK/M-linker/TMR-KLA-C $=3.5 / 1 / 2$, for example, $[\mathrm{PLK}]=0.10$ $\mathrm{mg} \mathrm{ml}^{-1}, \quad[\mathrm{M}$-linker $]=0.14 \mathrm{~mm}, \quad[$ TMR-KLA-C $]=0.27 \mathrm{~mm}$ ). Finally, $300 \mu \mathrm{l}$ of the HEPES buffer was added to the conjugate solution (total $500 \mu \mathrm{l}$ ), and $50 \mu \mathrm{l}$ of the solution was dispensed into a well of a 96-well culture plate (Falcon, BD Biosciences, San Jose, CA, USA) for immobilization and incubated for 4, 24 or $30 \mathrm{~h}$. After immobilization, the well was washed with $200 \mu \mathrm{l}$ each of phosphate-buffered saline (Gibco, Tokyo, Japan) and MilliQ water and was airdried on a clean bench.

\section{Peptide photo-release and quantitative determination of the released peptide concentration}

An aliquot of $100 \mu \mathrm{l}$ of MilliQ water was added to the peptide-immobilized wells in a 96-well plate. Then, UV light was irradiated from $20 \mathrm{~cm}$ above (irradiation area: 5 wellsx 5 wells) using a UV-spot light source (Photocure 200, Hamamatsu Photonics, Hamamatsu, Japan) with a band-pass filter $(362 \pm 30 \mathrm{~nm})$ and condenser lens (Photocure 200 series, E5147-06) for obtaining homogeneous UV irradiation. After irradiation, the peptide-released solution from the wells was collected, then a guanidine buffer $(20 \mathrm{~mm}$ Tris- $\mathrm{HCl}$ containing $6 \mathrm{~m}$ guanidine hydrochloride ( $\mathrm{pH} \mathrm{7))}$ was added to the wells for washing and the buffer was collected (final volume $1 \mathrm{ml}$ ). The released peptide concentrations were determined by measuring the TMR absorbance of the collected peptides.

\section{Cell-toxicity assay with the peptide photo-release system}

The cells $\left(2 \times 10^{3}\right.$ cells per well) were seeded in $100 \mu$ media (Dulbecco's modified Eagle's medium supplemented with $1 \%$ fetal bovine serum (BioWest, Nuaillé, France)) per well of the peptide-immobilizing plate. After overnight culture, the media were removed and the cells were gently washed three times with the assay media ( $5 \mathrm{~g}$ Dulbecco's modified Eagle's medium powder (SigmaAldrich, Tokyo, Japan) and $1.85 \mathrm{~g} \mathrm{NaHCO}_{3}$ (Wako Pure Chemical Industries) in $500 \mathrm{ml}$ MilliQ that was filtered with a $0.45 \mu \mathrm{M}$ syringe filter). Next, $100 \mathrm{U} \mathrm{ml}^{-1}$ penicillin (Sigma-Aldrich) and $100 \mu \mathrm{g} \mathrm{ml}^{-1}$ streptomycin (SigmaAldrich) were added to the filtered solution. After adding $100 \mu \mathrm{l}$ of the assay media, UV light was irradiated from $20 \mathrm{~cm}$ above using the UV-spot light source with a band-pass filter $(362 \pm 30 \mathrm{~nm})$ and a condenser lens at $37^{\circ} \mathrm{C}$. After irradiation, the cells were incubated for $2 \mathrm{~h}$ at $37^{\circ} \mathrm{C}$ in a $5 \% \mathrm{CO}_{2}$ environment. The cells were then incubated with $5 \mu \mathrm{l}$ of Cell Counting Kit-8 (Dojindo Laboratories, Kumamoto, Japan) solution for $4 \mathrm{~h}$. The absorbance at $450 \mathrm{~nm}$ was measured using a Benchmark Multiplate Reader (Bio-Rad Laboratories, Tokyo, Japan) at $30^{\circ} \mathrm{C}$. The difference in absorbance between the control and TMR-KLA-C peptide-treated samples was calculated to determine the degree of viability associated with each cell. The relative viability was calculated by dividing the absorbance of tested cells by that of control cells incubated without an immobilized peptide (non-coating) and with light irradiation (60 min) under normal growth conditions (assuming that $100 \%$ viability $=0 \%$ toxicity).

\section{RESULTS AND DISCUSSION}

We selected KLAKLAKKLAKLAKKLAKLAK (KLA) peptide as a model peptide for achievement of this system (Figure 1c), because it had previously shown a high degree of cell penetration and cytotoxicity. ${ }^{28}$ We added Gly (as a linker) and Cys (for immobilization) to the C terminus of the KLA sequence, and Gly and TMR to the $\mathrm{N}$ terminus of the sequence for detection, resulting in the sequence TMR-KLA-C. Using this peptide, optimization of the immobilization method was initially conducted.

An outline of the immobilization method is as follows: Initially, a photo linker (Figure 1b) was activated as succinimidyl ester for $2 \mathrm{~h}$, and the activated ester was coupled with poly-L-lysine (PLK) for $30 \mathrm{~min}$. Next, the peptide was attached via the thiol of Cys in sequence (Figure 1c) with the M-linker maleimide. Finally, the TMRKLA-C peptide-M-linker-PLK conjugate was immobilized on the 96well plastic bottom plate. First, we compared conditions, such as PLK m.w. (15-30, 75-150 or $150-300 \mathrm{kDa}$ ), PLK concentrations (from $0.010-0.20 \mathrm{mg} \mathrm{ml}^{-1}$ ) and immobilization times $(4,24$ or $30 \mathrm{~h}$ ) for method optimization. After immobilization of the TMR-KLA-C peptide, the immobilized amounts were evaluated by TMR absorbance $(570 \mathrm{~nm})$. As shown in Figure 2, the peptide appeared to be immobilized more as the m.w. of PLK increased. This result implied that higher m.w. PLKs were more efficiently attached to the plastic plates, because loading peptides on PLK might influence the chemical properties of PLKs, lowering the PLK affinity to the plastic plates. Therefore, the peptide was well-immobilized using 150-300 kDa PLK, and the optimal concentration of PLK was $0.10 \mathrm{mg} \mathrm{ml}^{-1}$. The decrease of absorbance at $0.20 \mathrm{mg} \mathrm{ml}^{-1}$ may also be due to the decreased ability of PLK to attach to the plastic plates by high peptide loading. An incubation time of $30 \mathrm{~h}$ was selected for further experiments.

After selecting $0.10 \mathrm{mg} \mathrm{ml}^{-1}$ of $150-300 \mathrm{kDa}$ PLK and $30 \mathrm{~h}$ immobilization time as the conditions for the following experiments, the light-irradiation time for peptide release was optimized. As shown in Figure 3a, the peptide release increased as the irradiation time was prolonged, and irradiation for more than $120 \mathrm{~min}$ appeared to produce saturation. Next, we studied the relative cell viability after light irradiation. Human cervix carcinoma (HeLa) and mouse embryonic fibroblast $(10 \mathrm{~T} 1 / 2)$ cells were seeded at $2 \times 10^{3}$ cells per well in 96-well culture plates. After overnight culture, UV light was irradiated for $15,30,60$ or $90 \mathrm{~min}$. The number of living cells remaining after light irradiation was counted using the Cell Counting Kit-8, which was previously optimized, ${ }^{15}$ and then the relative cell viability associated with each peptide concentration was determined. As shown in Figure 3b, more than 60 min of irradiation lowered the viability (cytotoxicity) both for HeLa and $10 \mathrm{~T} 1 / 2$ cells, although $365 \mathrm{~nm}$ UV light was proven harmless to cells for up to $60 \mathrm{~min}$. In conjunction with these results, we concluded that the optimal irradiation time for this system was $60 \mathrm{~min}$.

Next, we studied the cytotoxicity of the free peptide (peptide solution, not immobilized). HeLa and 10T1/2 cells were seeded at $1 \times 10^{3}$ cells per well in 96-well culture plates. After overnight culture, various concentrations of peptide solution were applied to the wells, and the cells were incubated for $2 \mathrm{~h}$ at $37^{\circ} \mathrm{C}$. The number of living cells remaining after peptide exposure was counted using the Cell Counting Kit-8, and the relative cell viability associated with each peptide concentration was determined. The TMR-KLA-C peptide demonstrated dose-dependent cytotoxicity in the concentration range 

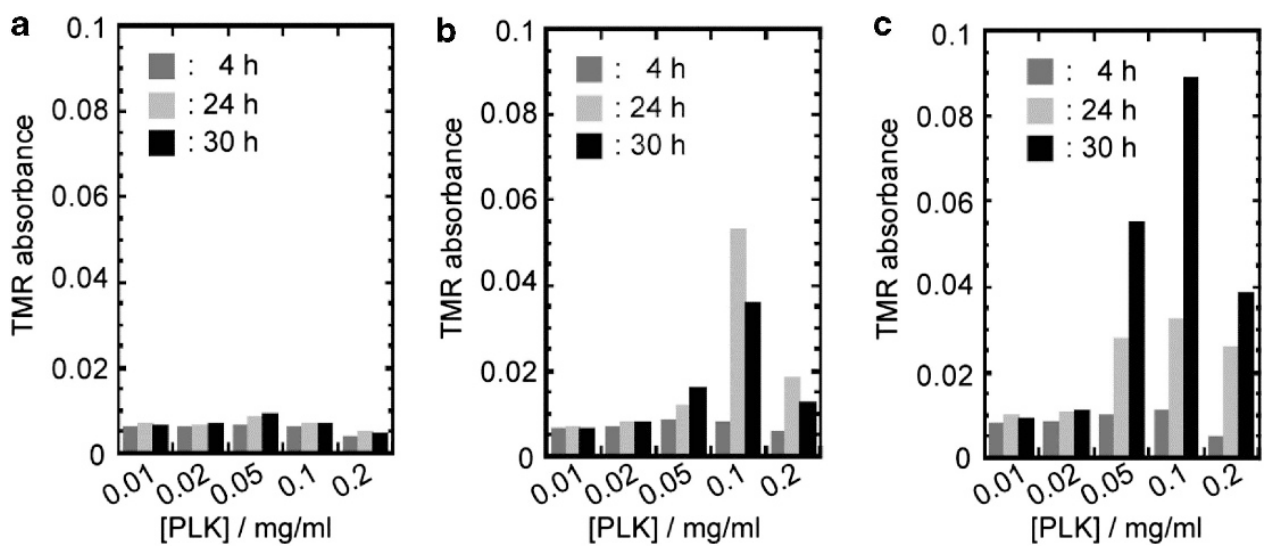

Figure 2 TMR (5-(and-6)-carboxytetramethylrhodamine) absorbance after immobilization of the TMR-GKLAKLAKKLAKLAKKLAKLAKGC (TMR-KLA-C) peptide with (a) 15-30 kDa poly-L-lysine hydrobromide (PLK), (b) 75-150 kDa PLK and (c) 150-300 kDa PLK for 4, 24 or 30 h (immobilization time).
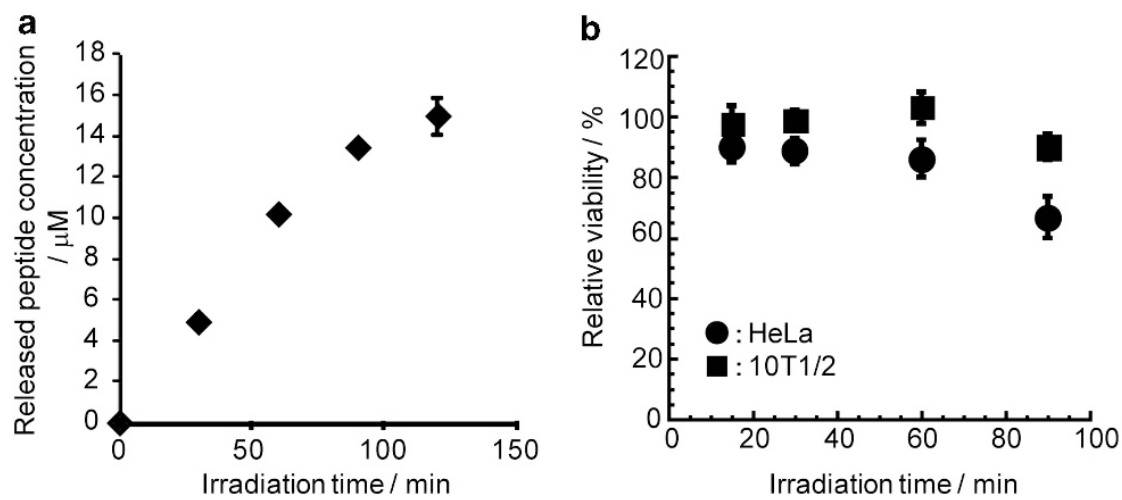

Figure 3 (a) Relationship between light irradiation time and released peptide concentration (TMR-GKLAKLAKKLAKLAKKLAKLAKGC (TMR-KLA-C peptide)) in the photo-cleavage system. (b) Relationship between light-irradiation time and HeLa or 10T1/2 relative cell viability. The relative viability was calculated by dividing the absorbance of tested cells by that of control cells without light irradiation (assuming that $100 \%$ viability $=0 \%$ toxicity).

of 5-20 $\mu \mathrm{M}$ (Supplementary Figure S1), although less than $5 \mu \mathrm{M}$ of peptide was harmless to the two cell types. This finding indicated that more than $10 \mu \mathrm{M}$ of the released peptide with light irradiation might be necessary for cell toxicity using the peptide-immobilized array.

Next, we checked whether the immobilized peptide-coated plate showed cytotoxicity. HeLa, 10T1/2 and African green monkey kidney (COS7) cells were seeded at $2 \times 10^{3}$ cells per well in the TMR-KLA-C immobilized plates. The cell viability assay was conducted using the Cell Counting Kit-8. As shown in Supplementary Figure S2, the immobilized TMR-KLA-C peptide was harmless to the three cells, although the PLK-coating was remarkably cytotoxic to HeLa cells. This result also implied that the peptide was completely and precisely immobilized onto the plastic plate wells in this immobilization procedure. It is noteworthy that the immobilized peptide showed no cytotoxicity; therefore, cells could be cultured on the peptideimmobilizing plate from the beginning of the experiment.

Finally, a cell-toxicity assay with this system for HeLa, 10T1/2 and COS7 cells was demonstrated. HeLa, 10T1/2 and COS7 cells were seeded at $2 \times 10^{3}$ cells per well in the TMR-KLA-C-immobilized plates. After overnight culture, UV light was irradiated for $60 \mathrm{~min}$, and the cells were incubated for $2 \mathrm{~h}$ at $37^{\circ} \mathrm{C}$. The cell viability was examined using the Cell Counting Kit-8. As shown in Figure 4 , all the cells showed $\sim 25 \%$ lowering of viability with the TMR-KLA-C peptide after light irradiation when compared with the non-coated plate with light irradiation. These results nearly correspond to the result of the free peptide solution assay at $10 \mu \mathrm{M}$ (Supplementary Figure S1). In addition, TMR-L8K6-C (TMRGLKKLLKLLKKLLKLGC-NH${ }_{2}$ )-immobilized plates were used for demonstration of a lower toxic representative than the TMR-KLAC-immobilized plates. As shown in Supplementary Figure S3, TMRL8K6-C was nearly non-toxic as expected. This finding implied that under this system, the cytotoxicity of peptides may vary depending on their sequences. Consequently, we successfully immobilized the peptide via the photo-cleavable linker and released the peptides by UV irradiation spatiotemporally, allowing examination of the peptide cytotoxicity in the three cell lines.

\section{CONCLUSIONS}

In this study, we constructed a novel peptide-array format system with a photo-cleavage linker for cellular toxicity analysis. Initially, we optimized the immobilization method and found that $0.10 \mathrm{mg} \mathrm{ml}^{-1}$ of $150-300 \mathrm{kDa}$ PLK with $30 \mathrm{~h}$ immobilization was optimal for coating the peptide to wells in a plastic culture 96-well plate. Next, light-irradiation time for the peptide release was optimized, and 60 min irradiation was selected because it was proven to be harmless to cells, although the released peptide increased as the irradiation time was prolonged. We also found that the immobilized peptide had no cytotoxicity. Consequently, cells could be cultivated on the peptide- 


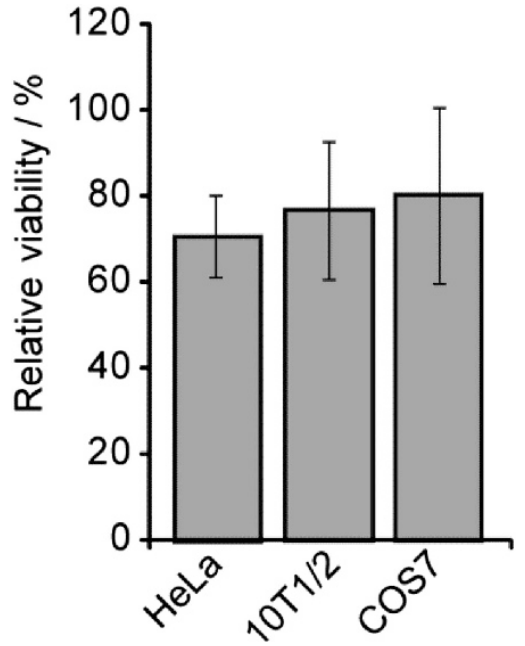

Figure 4 Cell-toxicity assay with the photo-release system using HeLa, $10 T 1 / 2$ and cos7 cells with the TMR-GKLAKLAKKLAKLAKKLAKLAKGC (TMR-KLA-C). The relative viability was calculated by dividing the absorbance of tested cells by that of control cells on non-coated wells with light irradiation for $60 \mathrm{~min}$ (assuming that $100 \%$ viability $=0 \%$ toxicity).

coated plate from the beginning of the experiment. Finally, a celltoxicity assay with this system for HeLa, 10T1/2 and COS7 cells was performed. All of the cells showed $\sim 25 \%$ lowering of viability ( $\sim 75 \%$ viability) with the TMR-KLA-C peptide compared with the non-coated plate (without the TMR-KLA-C peptide). In conclusion, we successfully immobilized the peptide with PLK via the photocleavable linker to commercially available culture plates and released the peptide by UV irradiation at times and well locations chosen at will. As a result, we conducted the cell-toxicity assay for HeLa, 10T1/2 and COS7 cells with the system. Under the current conditions, $60 \mathrm{~min}$ of irradiation is rather long for using this system in practical applications. Therefore, in the next study we will attempt to improve light condensation and/or miniaturize the system using an optical fiber or two-photon excitation fluorescence microscopy. With these improvements, the novel array format can make the peptide array an effective and high-throughput assay system for cellomics analyses and cell-based phenotypic drug screenings.

\section{ACKNOWLEDGEMENTS}

We thank Dr M Nakamura (Tokyo University of Pharmacy and Life Sciences, Tokyo, Japan) and Dr T Takahashi (Gunma University, Japan) for valuable discussions and generous support. This study was supported in part by grants from the Ministry of Education, Culture, Sports, Science and Technology (MEXT) and the Japan Science and Technology Agency. K.U. is also grateful to the Grants-in-Aid for Scientific Research, the 'Core Research' project (2009-2014) from MEXT. K.-y.T. acknowledges the Ryukoku University Science and Technology Fund.

1 Stockwell, B. R. Exploring biology with small organic molecules. Nature 432, 846-854 (2004).
2 Kandpal, R., Saviola, B. \& Felton, J. The era of 'omics unlimited. Biotechniques 46, 351-355 (2009).

3 Fernandes, T. G., Diogo, M. M., Clark, D. S., Dordick, J. S. \& Cabral, J. M. Highthroughput cellular microarray platforms: applications in drug discovery, toxicology and stem cell research. Trends Biotechnol. 27, 342-349 (2009).

4 Usui, K., Takahashi, M., Nokihara, K. \& Mihara, H. Peptide arrays with designed alphahelical structures for characterization of proteins from FRET fingerprint patterns. Mol. Divers. 8, 209-218 (2004).

5 Usui, K., Ojima, T., Takahashi, M., Nokihara, K. \& Mihara, H. Peptide arrays with designed secondary structures for protein characterization using fluorescent fingerprint patterns. Biopolymers 76, 129-139 (2004).

6 Usui, K., Tomizaki, K. -Y., Ohyama, T., Nokihara, K. \& Mihara, H. A novel peptide microarray for protein detection and analysis utilizing a dry peptide array system. Mol. Biosyst. 2, 113-121 (2006).

7 Usui, K., Tomizaki, K. -Y. \& Mihara, H. Protein-fingerprint data mining of a designed alpha-helical peptide array. Mol. Biosyst. 2, 417-420 (2006).

8 Usui, K., Tomizaki, K.-Y. \& Mihara, H. Screening of alpha-helical peptide ligands controlling a calcineurin-phosphatase activity. Bioorg. Med. Chem. Lett. 17, 167-171 (2007).

9 Usui, K., Tomizaki, K. -Y. \& Mihara, H. A designed peptide chip: protein fingerprinting technology with a dry peptide array and statistical data mining. Methods Mol. Biol. 570, 273-284 (2009).

10 Kodadek, T. Development of protein-detecting microarrays and related devices. Trends Biochem. Sci. 27, 295-300 (2002).

11 Tomizaki, K. -Y., Usui, K. \& Mihara, H. Protein-detecting microarrays: current accomplishments and requirements. Chembiochem 6, 782-799 (2005).

12 Uttamchandani, M. \& Yao, S. Q. Peptide microarrays: next generation biochips for detection, diagnostics and high-throughput screening. Curr. Pharm. Des. 14 2428-2438 (2008).

13 Tomizaki, K.-Y., Usui, K. \& Mihara, H. Proteins: Array-Based Techniques. (ed. Begley, T. P.) 144-158 (Wiley Encyclopedia of Chemical Biology, 2009).

14 Tomizaki, K. Y., Usui, K. \& Mihara, H. Protein-protein interactions and selection: arraybased techniques for screening disease-associated biomarkers in predictive/early diagnosis. FEBS J 277, 1996-2005 (2010).

15 Usui, K., Kakiyama, T., Tomizaki, K.-Y., Mie, M., Kobatake, E. \& Mihara, H. Cell fingerprint patterns using designed $\alpha$-helical peptides to screen for cell-specific toxicity. Bioorg. Med. Chem. Lett. 21, 6281-3284 (2011).

16 Jiang, X., Ferrigno, R., Mrksich, M. \& Whitesides, G. M. Electrochemical desorption of self-assembled monolayers noninvasively releases patterned cells from geometrical confinements. J. Am. Chem. Soc. 125, 2366-2367 (2003).

17 Ryan, D., Parviz, B. A., Linder, V., Semetey, V., Sia, S. K., Su, J., Mrksich, M. \& Whitesides, G. M. Patterning multiple aligned self-assembled monolayers using light. Langmuir 20, 9080-9088 (2004).

18 Carrico, I. S., Maskarinec, S. A., Heilshorn, S. C., Mock, M. L., Liu, J. C., Nowatzki, P. J., Franck, C., Ravichandran, G. \& Tirrell, D. A. Lithographic patterning of photoreactive cell-adhesive proteins. J. Am. Chem. Soc. 129, 4874-4875 (2007).

19 Veiseh, M., Veiseh, O., Martin, M. C., Asphahani, F. \& Zhang, M. Short peptides enhance single cell adhesion and viability on microarrays. Langmuir 23, 4472-4479 (2007).

20 Holmes, C. P. \& Jones, D. G. Reagents for combinatorial organic synthesis: development of a new o-nitrobenzyl photolabile linker for solid phase synthesis. J. Org. Chem. 60, 2318-2319 (1995).

21 Whitehouse, D. L., Savinov, S. N. \& Austin, D. J. An improved synthesis and selective coupling of a hydroxy based photolabile linker for solid phase organic synthesis. Tetrahedron Lett. 38, 7851-7852 (1997).

22 Rinnová, M., Nováková, M., Kasicka, V. \& Jirácek, J. Side reactions during photochemical cleavage of an alpha-methyl-6-nitroveratryl-based photolabile linker. J. Pept. Sci. 6, 355-365 (2000).

23 Nakayama, K., Tachikawa, T. \& Majima, T. Protein recording material: photorecord/ erasable protein array using a UV-eliminative linker. Langmuir 24, 1625-1628 (2008).

24 Zhang, Y., Dong, Z., Nomura, M., Zhong, S., Chen, N., Bode, A. M. \& Dong, Z. Signal transduction pathways involved in phosphorylation and activation of p70S6 K following exposure to UVA irradiation. J. Biol. Chem. 276, 20913-20923 (2001).

25 Soughayer, J. S., Wang, Y., Li, H., Cheung, S. -H., Rossi, F. M., Stanbridge, E. J., Sims, C. E. \& Allbritton, N. L. Characterization of TAT-mediated transport of detachable kinase substrates. Biochemistry 43, 8528-8540 (2004).

26 Hoff, A., André, T., Fischer, R., Voss, S., Hulko, M., Marquardt, U., Wiesmüller, K. -H. \& Brock, R. Chemolabile cellular microarrays for screening small molecules and peptides. Mol. Divers. 8, 311-320 (2004).

27 Chan, W. C. \& White, P. D. Fmoc Solid Phase Peptide Synthesis: A Practical Approach (Oxford University Press, New York, 2000).

28 Ellerby, H. M., Arap, W., Ellerby, L. M., Kain, R., Andrusiak, R., Rio, G. D., Krajewski, S., Lombardo, C. R., Rao, R., Ruoslahti, E., Bredesen, D. E. \& Pasqualini, R. Anticancer activity of targeted pro-apoptotic peptides. Nat. Med. 5, 1032-1038 (1999).

Supplementary Information accompanies the paper on Polymer Journal website (http://www.nature.com/pj) 